\title{
Distribution of Buglossoides arvensis (L.) I.M.Johnst. (Boraginaceae) in South America: new records for the floras of Chile, Bolivia, Peru and Colombia
}

\section{Distribución de Buglossoides arvensis (L.) I.M.Johnst. (Boraginaceae) en Sudamérica: nuevos registros para las floras de Chile, Bolivia, Perú y Colombia}

\author{
Maximilian Weigend ${ }^{1} \&$ Miguel Alvarez $2^{*}$ \\ ${ }^{1}$ Nees-Institute, Rheinische Friedrich-Wilhelms-Universität, Meckenheimer Allee 170, 53115 Bonn, Germany. \\ ${ }^{2}$ INRES-Institute, Rheinische Friedrich-Wilhelms-Universität, Karlrobert-Kreiten-Str. 13, 53115 Bonn, Germany. \\ *malvarez@uni-bonn.de
}

\begin{abstract}
RESUMEN
Buglossoides arvensis (L.) I.M. Johnst. (Boraginaceae), una maleza de origen euroasiático, sólo ha sido mencionada en Sudamérica para las floras de Argentina y Uruguay. En este trabajo se amplía su distribución en el continente para Bolivia, Chile, Colombia y Perú, donde esta especie ha sido observada como maleza de cultivos y en ambientes alterados. También se sospecha su presencia en Ecuador y una frecuencia mucho mayor a la actualmente conocida en Bolivia, Chile y Colombia.
\end{abstract}

The genus Buglossoides Moench. with ca. 10 species was segregated from the larger genus Lithospermum L. by Johnston (1954) based on characters of the corolla and the nutlets. This segregation has recently been confirmed applying molecular markers by Thomas et al. (2008) and Weigend et al. (2009). Lithospermum is widespread throughout the northern hemisphere and has a range of native and endemic species in the Americas including several recently described species in South America (Weigend et al. 2010). Conversely, Buglossoides -like most genera of the tribe Lithospermeae Dumort.- is native only to Eurasia (Weigend et al. 2009). Buglossoides arvensis (synonymous Lithospermum arvense) is the most widespread species and is a common agricultural weed in western Eurasia (Tutin et al. 1996). The species is known as an introduced weed in Australia (Auld \& Medd 1987), South Africa (Retief \& Van Wyk 2002) and North America (Kartesz \& Kartesz 1980). In recent years, $B$. arvensis has been also reported in Argentina and Uruguay (Zuloaga et al. 2008); however, $B$. arvensis is not currently reported from other South American countries. For instance, it is neither mentioned in any flora from Ecuador, Peru, Bolivia, Colombia or Chile (Brako \& Zarucchi 1993, Jørgensen \& León-Yánez 1999, Zuloaga et al. 2008) nor in floras focussed on weeds in some of those countries (i.e. Sagástegui \& Leiva 1993, Matthei 1995), although some specimens collected in Peru and Bolivia are mentioned in online databases such as Tropicos (URL: $\mathrm{http} / /$ www.tropicos.org). On the basis of own revisions of specimens vouchers and own collections we report herewith the occurrence of $B$. arvensis in the floras of Bolivia, Chile, Colombia and Peru. Additional information on the distribution of this species in South America were obtained from Zuloaga et al. (2008) and the Tropicos data base (op. cit.). The relatively abundant collections from Peru argue that this species is commonly ignored and overlooked by botanists and is likely a widespread introduced weed.

\section{DESCRIPTION}

Buglossoides arvensis (L.) I.M. Johnst., J. Arnold Arbor. 35(1): 42. 1954. 三Lithospermum arvense L., Sp. Pl. 1: 132, 1753 (holotype: L. arvense, LINN 181.4).

Synonyms: Lithospermum officinale Molfino, hom. illeg., Aegonychon arvense Gray, Margarospermum arvense Decne., Rhytispermum arvense (L.) Link.

Annual, erect herb, $10-50 \mathrm{~cm}$ tall. Branched from the base, stem to $3 \mathrm{~mm}$ in diam., covered with white trichomes $(0.3-0.8 \mathrm{~mm})$. Leaves alternate, sessile; lamina oblong to narrowly ovate or obovate, $13-35 \times 0.2-0.8 \mathrm{~mm}$, base semiamplexicaul, apex acuminate, margin entire; acroscopic accumbend indument, adaxial surface densely covered with white trichomes (0.3-1.0 $\mathrm{mm}$ ), abaxial surface with numerous trichomes on the midrib and trichomes scattered on the lamina $(0.3-0.8 \mathrm{~mm})$; only the midvein from base to apex. Inflorescences weakly scorpioid dichasia, rarely monochasia, 3-16 cm long, with (5-) 8 (-12) flowers per monochasium, frondose; pedicels $0.2-2.0 \mathrm{~mm}$ long. Flowers pentamerous (Fig. 1a); calyx free nearly to base, 
calyx lobes narrowly ovate, 4.7-5.2 x 0.6-0.9 mm, densely covered with trichomes $(0.5-1.0 \mathrm{~mm})$. Corolla salverform, $4.7 \mathrm{~mm}$ long; tube cylindrical to tubular, ca. $3.0 \times 1.7 \mathrm{~mm}$, corolla lobes widely ovate to subcircular, $0.8-1.3 \times 0.5-1.0$ $\mathrm{mm}$, base few narrowed, apex rounded, with papillose regions at the corolla mouth, white, seldom brownish. Stamens 5, filaments epipetalous, inserted ca. $1.0 \mathrm{~mm}$ from base, $0.4 \mathrm{~mm}$ long, anthers ovoidal, $0.9 \times 0.3 \mathrm{~mm}$. Gynoeceum superior, gynobasic, with 4-parted ovary and basal ring nectary, style columnar, $1.0 \mathrm{~mm}$ long, stigma conical with basal bilobed, stigmatic ring. Nutlets $3.1 \times 1.7 \mathrm{~mm}$, triangular-ovoidal, verrucose and irregularly grooved, areola subcircular, greyish brown (Fig. 1b-d). 2n = 14, 28, 36, 42 .

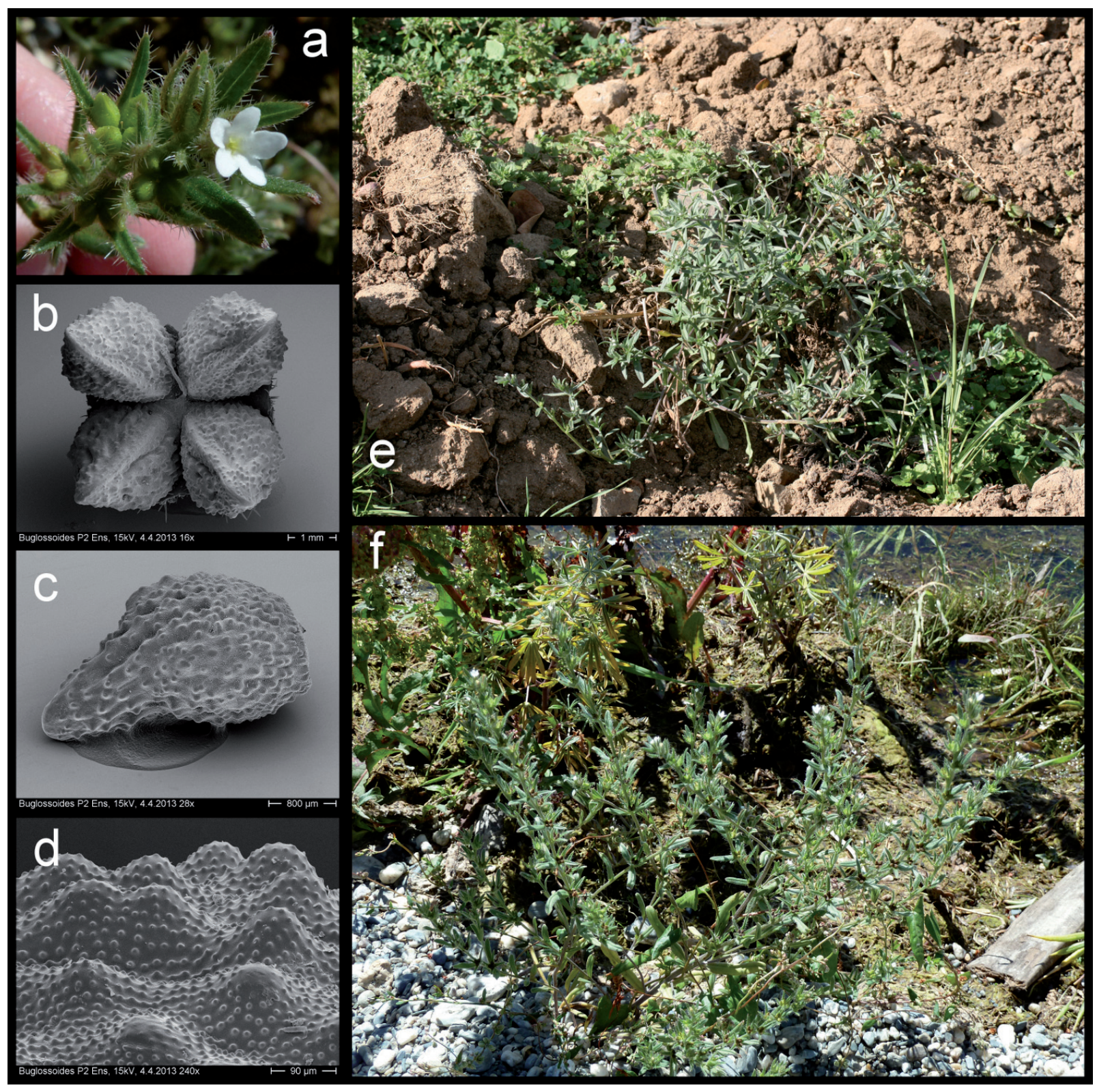

FIGURE 1. Morphology and habitats of Buglossoides arvensis. Details of inflorescence and flower (a), top view of the fruits (b), diagonal view of a nutlet (c) and detail of its surface (d). Occurrence of the species as weed in arable lands from the Peruvian highlands (Ancash) (e) and as ruderal in a lakeshore from Patagonia, Puerto Guadal, Chile (f).

Figura 1. Morfología y hábitats de Buglossoides arvensis. Detalle de la inflorescencia y una flor (a), vista superior de los frutos (b), vista diagonal de una núcula (c) y detalle de su superficie (d). Presencia de la especie como maleza de cultivos en el Altiplano peruano (Ancash) (e) y como especie ruderal en riveras lacustres de la Patagonia, Puerto Guadal, Chile (f). 


\section{Material STUdied}

ARGENTINA: Prov. La Pampa, Gral. Acha, near to Ataliva Roca, 01-XII-1959, O. Boelke 8199 (MO); Depto. Mendoza, Prov. Tunujan, Campo los Andes, 11-X-1943, G. Covas 2797 (F, MO); Depto. Buenos Aires, Villa Progreso, on the railways of the tram, 24-X-1931, C. M. Hicken 14493 (MO); Depto. Pilcaniyeu, Prov. Rio Negro, Road from San Carlos de Bariloche to Comallo, near Lago Perito Moreno, Road km 597, 983 m, 10-I-2002, Weigend et al. 5820 (BRCO, BSB, MSB). BOLIVIA: La Paz, Prov. Bautista Saavedra, Amarete, on the road to Saganacon, 3850 m, 26-I-1980, T. Feuerer 8141 (H). CHILE: Región de Aysén, Puerto Guadal, shoreline of the Lake General Carrera, on gravels, 219 m, 16-II-2012, M. Alvarez 1017 (B, VALD). COLOMBIA: Depto. Magdalena, Río Frío, between the Cienaga de Santa Marta and the foothills, 0-100 m, 22-30-VI-1906, H. Pittier 1613 (NY). PERU: Dept. Lambayeque, Distr. Incahuasi, Incahuasi, road to Huasicaj, $2960 \mathrm{~m}$, 12-VII-1992, S. Llatas Quiroz 3178 (F); Dept. La Libertad, Prov. Otuzco, La Libertad, Above Shingo-Shitahuara, 3100 m, 04-VI1990, A. Sagástegui \& P. Leiva 102 (F); Prov. Otuzco, road Otuzco to Usquil, 3263 m, 18-IV-2004, M. Weigend \& Ch. Schwarzer 7882 (BSB); Dept. Cajamarca Prov. Cajamarca, $10 \mathrm{~km}$ from Cajamarca on road to Celendin, $3000 \mathrm{~m}, \mathrm{M}$. Weigend et al. 97/366 (F, MSB, CPUN, USM); new road from Bambamarca to Paccha, 2200-2400 m, III-1998, N. Dostert 98/15 (B, F, USM); Prov. Jaén, Sallique, from Catala to Piquijaca, 1940-2195 m, 29-VII-1998, J. Campos \& C. Díaz 5404 (USM); road Sihuas to Corongo/Yuramarca, on the north-facing slope above Río Sihuas near Ragash, 3627 m, 26-IV-2004, M. Weigend \& Ch. Schwarzer 8030 (BSB); Dept. Ancash, Prov. Huaylas, Cordillera Negra, road Caraz to Moro over Pamparomas, above Icha, 3141 m, 29IV-2004, M. Weigend \& Ch. Schwarzer 8074 (BSB); Prov. Huaylas, Pamparomas, 3000 m, 11-IV-2001, M. Weigend et al. 5540 (BSB, HSM, USM, MSB, HUSA).

\section{REMARKS}

Own observations done during collections in Peru were from weed communities in arable lands, for instance on potato and wheat fields (Fig. 1e), but also in disturbed sites along road sides and on construction sites, corresponding to the typical habitat types occupied in its native range (Tutin et al. 1996). Conversely, this species has been observed in Chile only on gravels in the shores of Lake General Carrera, close to the urbanized town Puerto Guadal as a ruderal species (Fig. 1f).

The current records suggest that this species has been introduced across temperate and Andean South America and may be expected in Ecuador and more frequently than currently reported in Bolivia and Chile (Fig. 2). Seeds are probably mostly dispersed by humans together with the grains of the cereals and self-dispersal is low, as is persistence of germinable diaspores in the soil seed bank
(Bischoff 2005). This species is considered as a weed with relatively low aggressiveness and likely represents no threat to native vegetation. However, the species is known to be poisonous (Everist 1981) and due to poor harvest processing techniques the introduction of its seed into the food chain cannot be ruled out, especially under traditional crop systems in Peru and Bolivia. With the locally highly abundance of the species in wheat and oat fields, especially in northern Peru, this may represent a certain danger to human health in this region.

While this species shows range expansion into the New World, in Central Europe populations are declining due to intensification of cropping systems and the continuous use of herbicides (Zippel \& Wilhalm 2003), so that recolonisation measurements are proposed (Bischoff 2005).

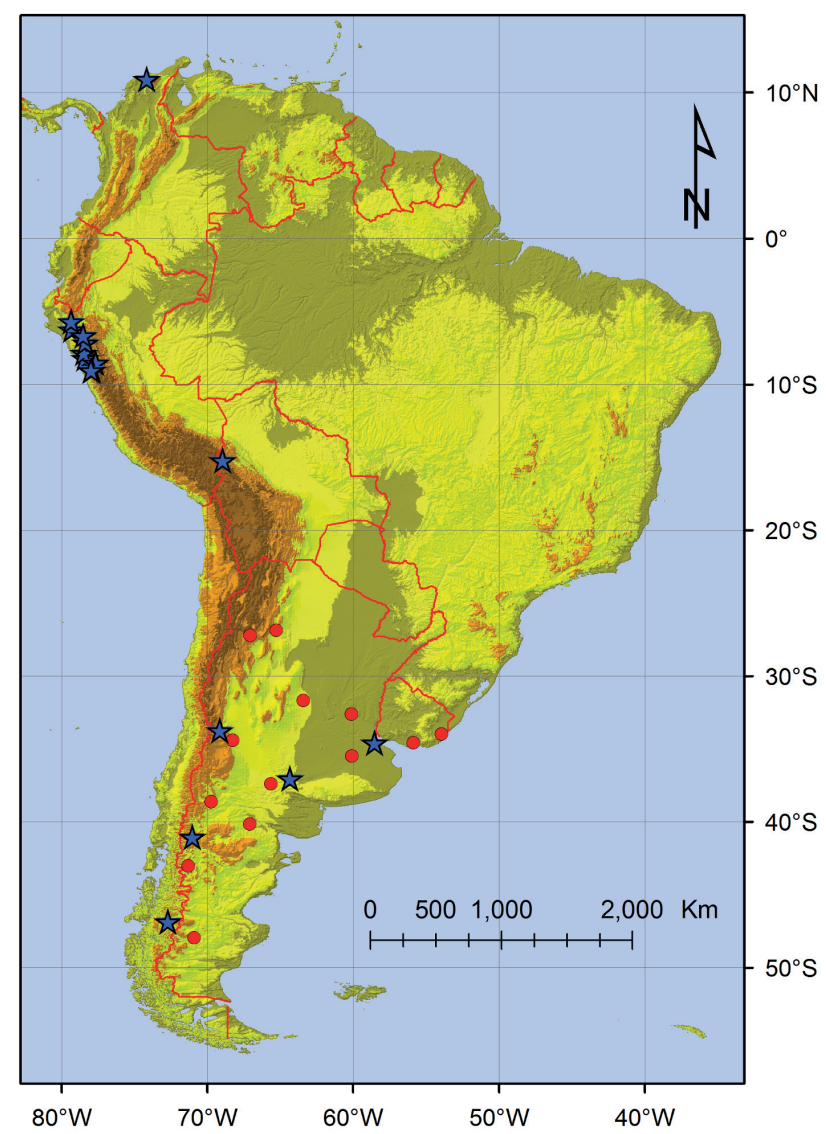

FIgURE 2. Distribution of Buglossoides arvensis in South America. Red circles show distribution according Zuloaga et al. (2008). Blue stars show collection localities of studied specimines including new records for Colombia, Peru, Bolivia and Chile.

Figura 2. Distribución de Buglossoides arvensis en Sudamérica. Círculos rojos muestran la distribución según Zuloaga et al. (2008). Estrellas azules muestran las localidades de colecta de los especímenes estudiados, incluyendo nuevos registros para Colombia, Perú, Bolivia y Chile. 


\section{ACKNOWLEDGEMENTS}

The second author thanks to the A.F.W. Schimper-Stiftung (Stuttgart, Germany) for its financial support of field collections in Chile.

\section{BIBLIOGRAPHY}

Auld, B.A. \& R.W. MedD. 1987. Weeds. An illustrated botanical guide to the weeds of Australia. Inkata Press, Melbourne. 255 pp.

Bischoff, A. 2005. Analysis of weed dispersal to predict chances of re-colonisation. Agriculture, Ecosystems and Environment 106: 377-387.

Brako, L. \& J.L. Zarucchi. 1993. Catalogue of the Flowering Plants and Gymnosperms of Peru. Monographs in Systematic Botany from the Missouri Botanical Garden 45: $1286 \mathrm{pp}$.

Everist, S.L. 1981. Poisonous Plants of Australia. Angus and Robertson, Sydney. 966 pp.

Johnston, I.M. 1954. Studies in the Boraginaceae. XXVI. Further revaluations of the genera of the Lithospermeae. Journal of the Arnold Arboretum 35: 1-81.

JørGENSEN, P.M. \& S. LEÓN-YÁnez. 1999. Catalogue of the vascular plants of Ecuador. Monographs in Systematic Botany from the Missouri Botanical Garden 75: 1182 pp.

Kartesz, J.T. \& R. Kartesz. 1980. A synonymized checklist of the vascular flora of the United States, Canada and Greenland. Vol. II. University of North Carolina Press, Chapel Hill. 498 pp.

Matthei, O. 1995. Manual de las malezas que crecen en Chile.
Alfabeta, Santiago. 545 pp.

Retief, E. \& A.E. VAN WyK. 2002. The genus Buglossoides (Boraginaceae) in South Africa. Bothalia 32: 9-13.

Sagástegui, A. \& S. Leiva. 1993. Flora invasora de los cultivos del Perú. Consejo Nacional de la Ciencia y Tecnología, Trujillo. $539 \mathrm{pp}$.

Thomas, D.C., M. Weigend \& H.H. Hilger. 2008. Phylogeny and systematics of Lithodora (Boraginaceae - Lithospermeae) and its affinities to the monotypic genera Neatostema, Mairetis, Halacsya and Paramoltkia based on ITS1 and $\operatorname{trn} \mathrm{L}_{\mathrm{UAA}^{-}}$ sequence data and morphology. Taxon 57: 79-97.

Tutin, T., N. Burges, A. Chater, J. Edmonson, V. Heywood, D. Moore, D. Valentine, S. Walters \& D. Webb. 1996. Flora Europaea. Cambridge University Press. 5 vols.

Weigend, M., F. Selvi, M. Gottschling \& H.H. Hilger. 2009. Marbleseeds are Gromwells - systematics and evolution of Lithospermum L. s.l. (Boraginaceae tribe Lithospermeae) based on molecular and morphological data. Molecular Phylogenetics and Evolution 52: 755-768.

Weigend, M., M. GotTschling, N.M. Nürk \& H.H. Hilger. 2010. Five new species of Lithospermum L. (Boraginaceae tribe Lithospermeae) in Andean South America: another radiation in the Amotape-Huancabamba Zone. Taxon 59: 1161-1179.

Zippel, E. \& T. Wilhalm. 2003. Nachweis und Verbreitung annueller Buglossoides-Arten (Lithospermeae, Boraginaceae) in Südtirol (Italien). Gredleriana 3: 347-359.

Zuloaga, F.O., O. Morrone \& M.J. Belgrano. 2008. Catálogo de las plantas vasculares del cono sur (Argentina, Sur de Brasil, Chile, Paraguay y Uruguay). Monographs of the Missouri Botanical Garden 107: 3348 pp.

Recibido: 23.04.13

Aceptado: 12.12 .13 